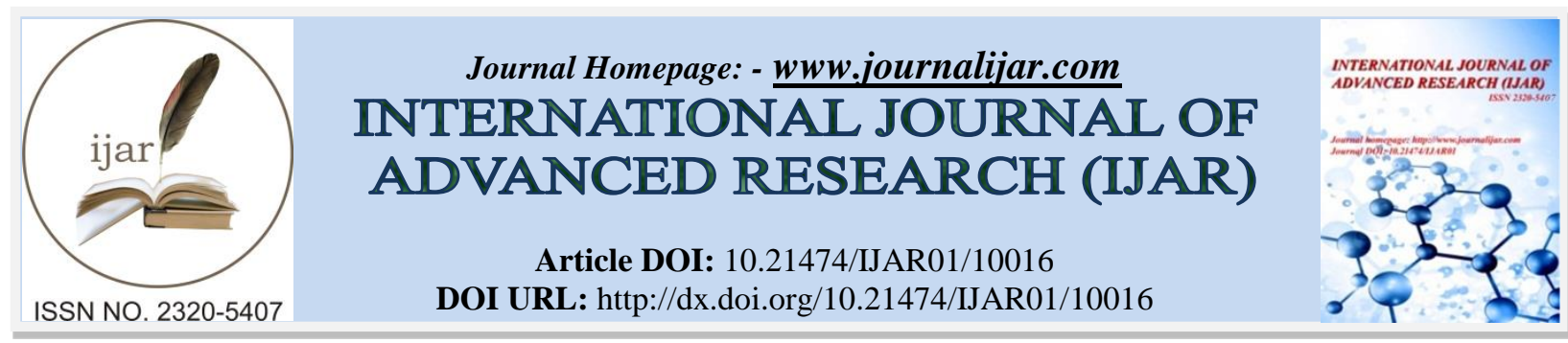

RESEARCH ARTICLE

\title{
IN VITRO PROPAGATION OF CHRYSANTHEMUM (CHRYSANTHEMUM INDICUM L) WITH BENZYL AMINO PURINE AND NAPHTALENE ACETIC ACID SUPPLEMENTATION.
}

Rosmaria Girsang and Armaniar and Refnizuida.

Department of Agroecotechnology, Faculty of Agriculture, Pembangunan Panca Budi University, Medan, Indonesia.

\section{Manuscript Info}

\section{Manuscript History}

Received: 08 September 2019

Final Accepted: 10 October 2019

Published: November 2019

Key words:-

Chrysanthemum (Chrysanthemum indicum L), Naphthalene acetic acid (NAA), Benzil amino purine (BAP).

\begin{abstract}
The in vitro propagation of the plant is a developed method in tissue culture. This method is developed to propagate the Chrysanthemum (Chrysanthemum indicum $\mathrm{L}$ ). The purpose of this research was to find out the Benzyl Amino Purine (BAP) and Naphtalene Acetic Acid (NAA) supplementation towards the in vitro Chrysanthemum multiplication. The method used was the factorial Completely Randomized Design with two factors used, those were factor I: NAA consisted of 3 treatment levels: $(\mathrm{N} 0)=$ Control without NAA. $(\mathrm{N} 1)=$ $1 \mathrm{ml} / 1$ NAA. $(\mathrm{N} 2)=1.5 \mathrm{ml} / \mathrm{L}$ NAA. $(\mathrm{N} 3)=2 \mathrm{ml} / \mathrm{L}$ NAA. Factor II: growth regulator $(\mathrm{BAP})$ consisted of 3 treatment levels $(\mathrm{B} 0)=$ Without BAP Treatment as Control. (B1) $=1 \mathrm{ml} / \mathrm{L}$ BAP. (B2) $=1.5 \mathrm{ml} / \mathrm{L}$ BAP. (B3) $=2 \mathrm{ml} / \mathrm{L}$ BAP. The parameters observed were the number of roots, leaves and performed every week meanwhile the height, root length and the performance was observed after 8 weeks of propagation (8MST). The result shows, the addition of growth regulatory compounds (NAA and BAP) combinations took significant effect towards the parameters of the number of leaves meanwhile the plant height, number of roots and length of root were not significantly taken any effect.
\end{abstract}

Copy Right, IJAR, 2019,. All rights reserved.

\section{Introduction:-}

Chrysantemum might be called as short day plants when its flower initiation and development is depended on the sunlight. The propagation of chrysanthemum needs a large land to fulfil the needs of its consumers. This decorative plant has been widely in demand of people, yet there are some constraints felt by the farmers when producing chrysanthemum seedling. The seedling plants of Chrysanthemum (Chrysanthemum indicum L) often being attacked by th pests causing the change in its flower colour, less attractive and less guaranteeing the quality impact on consumers trust (Altayani, 2018).

Productivity and production of Chrysanthemum flower is increasing year to year implies the need huge availability of superior varieties and good quality of seedlings (Soedarjo, 2010). Based on Central Bureau of Statistics (BPS,2014), the Chrysanthemum production from year to year has been increasing to the number of 387.208 .754 stalks, and the increasement reaches the number of 427.248.059 stalks. The request of Chrysanthemum flowers in Indonesia keep increasing approximately $25 \%$ per year.

\section{Corresponding Author:- Rosmaria Girsang}

Address:- Department of Agroecotechnology, Faculty of Agriculture, Pembangunan Panca Budi University, Medan, Indonesia, Gatot Subroto Street, Km 4.5 Medan, Indonesia. 
The quality and consistency of Chrysanthemum has been the common problem. Other problem comes from the unstable Chrysanthemum prices with unstable quality. The propagation of Chrysanthemum by the farmers is still using conventional method with shoot cutting. These cuttings may cause a decrease in Chrysanthemum crop productivity (Muhit, 2007). The most effective solution to produce high quality Chrysanthemum is by using tissue culture method to develop quality of numerous seedlings in a relatively short period of time compared to conventional propagation. This way is expected to overcome the problem of quality of Chrysanthemum seedlings availability (Yusnita, 2003)

In tissue culture, beside the explant which would be cultured, the growth regulators will affect a lot to the effectivity of Chrysanthemum growth. According to Sugiyanto (2008), NAA (Naphtalene acetic acid) is a stable auxin compared to others because it is not easily decomposed by enzymes released by the cells or in heating process of sterilization. This type of auxin is predisposing the stem length increase, growth, root differentiation and branching, fruit development, apical dominance, phototropism and geotropism. In addition, cytokinin can be also combined to the MS media. According to Kasli (2009), BAP (Benzil amino purine) has an important role in the Chrysanthemum shoot forming. One of the BAP functions is to propagate the plants by stimulating the shoot of the tissue culture explant. Therefore, this research is going to utilize NAA and BAP as growth regulator for in vitro propagation of Chrysanthemum. The purpose of this research is to find out the effectivity of NAA and BAP as growth regulator towards the in vitro propagation of Chrysanthemum (Chrysanthemum indicum L).

\section{Materials and methods:-}

This research was conducted in tissue culture laboratory of Panca Budi. The tools used were Laminar Air Flow Cabinet (LAFC), Autoclave, analytical balance, chiller and using and using standard tissue culture tools. The material used was Chrysanthemum explants (Chrysanthemum indicum L). This method used was factorial completely randomized design consisting of 2 treatments with 9 combinations of treatments and 3 repetition. With MS as basic media. With MS as media. There are 2 factors in this research, those are: Factor I : Administration of NAA dose in variation symbolized with $\mathrm{N}$, consisted by 3 levels which are: $(\mathrm{N} 0)=$ Control without $\mathrm{NAA},(\mathrm{N} 1)=1 \mathrm{ml} / \mathrm{L},(\mathrm{N} 2)=$ $2 \mathrm{ml} / \mathrm{L}$. Factor II: Administration of BAP dose in variation symbolized with B, consisted by 3 levels which are: $(\mathrm{B} 0)=$ control without BAP, $(\mathrm{B} 1)=1,5 \mathrm{ml} / \mathrm{L}(\mathrm{B} 2)=2 \mathrm{ml} / \mathrm{L}$. The observed parameters are number of leaves, plant height, roots number, roots length and propagate plants. Data collection technique performed during the research was with the observation of several parameters started from 2 weeks to 8 weeks of propagation.

\section{Results and Discussion:-}

Table 1:- Summary of Observation Parameter Variances of Chrysanthemum Propagation from 2 to 8 weeks of propagation.

\begin{tabular}{|c|c|c|c|c|c|c|}
\hline \multirow[t]{3}{*}{ Week of } & \multicolumn{6}{|c|}{ Observation from 1 to 12 Weeks of Propagation } \\
\hline & \multicolumn{3}{|c|}{ Number of Root } & \multicolumn{3}{|c|}{ Number of Leaf } \\
\hline & $\mathrm{N}$ & $\mathrm{B}$ & N\&B & $\mathrm{N}$ & $\mathrm{B}$ & $N \& B$ \\
\hline 2 & $1.13^{\#}$ & $1.02^{\#}$ & $0.29^{\#}$ & $2.84^{\#}$ & $0.70^{\#}$ & $1.09^{\#}$ \\
\hline 4 & $0.66^{\#}$ & $0.66^{\#}$ & $0.40^{\#}$ & $6.36^{*}$ & $0.40^{\#}$ & $1.07^{\#}$ \\
\hline 6 & $0.09^{\#}$ & $1.03^{\#}$ & $0.44^{\#}$ & $4.10^{*}$ & $1.16^{\#}$ & $2.55^{\#}$ \\
\hline \multirow[t]{4}{*}{8} & $0.04^{\#}$ & $1.19^{\#}$ & $0.74^{\#}$ & $2.91^{\#}$ & $1.39^{\#}$ & $3.31^{*}$ \\
\hline & \multicolumn{6}{|c|}{ Observation of Week 12 of Propagation } \\
\hline & \multicolumn{3}{|c|}{ Root length } & \multicolumn{3}{|c|}{ Plant height } \\
\hline & $1,95^{\#}$ & $2,27^{\#}$ & $0,75^{\#}$ & $1,16^{\#}$ & $0,69^{\#}$ & $2,15^{\#}$ \\
\hline
\end{tabular}

Table 2:- The Average Number of Leaves, Plant Height, Roots and Root Height in the 8 Weeks of propagation

\begin{tabular}{|l|l|l|l|l|}
\hline Treatment & Number of Leaf & Plant Height & Root Number & Root Length \\
\hline N0B0 & $9.6^{\text {ab }}$ & 5.60 & 3.33 & 3.83 \\
\hline N0B1 & $16.0^{a}$ & 8.83 & 12.00 & 9.10 \\
\hline N0B2 & $12.3^{a b}$ & 7.23 & 3.00 & 1.60 \\
\hline N1B0 & $13.6^{a b}$ & 9.50 & 6.67 & 4.17 \\
\hline N1B1 & $8.6^{\mathrm{bc}}$ & 3.93 & 4.00 & 0.30 \\
\hline N1B2 & $2.6^{c}$ & 1.77 & 3.00 & 0.20 \\
\hline N2B0 & $7.6^{c}$ & 5.43 & 5.00 & 0,80 \\
\hline
\end{tabular}




\begin{tabular}{|l|l|l|l|l|}
\hline N2B1 & $10.0 \mathrm{ab}$ & 4.00 & 22.00 & 1.10 \\
\hline N2B2 & $10.3 \mathrm{ab}$ & 5.93 & 1.00 & 0.50 \\
\hline
\end{tabular}

Information : Numbers followed by the same letter and in the same column show no significant difference at the 5\% level based on the Least Significant Difference (LSD) test.

According to the variation analysis, NAA and BAP interaction shows there is significant affect through the number of Chrysanthemum leaves. The best combination to give the highest average of total leaves number is in N2B2 treatment in the equal concentration of auxin and cytokinin gives a good respond to the growth of Chrysanthemum leaves. Ni'mah (2012) says that the exogenous BAP administration in the medium might affect the development and elongation of the cells significantly.

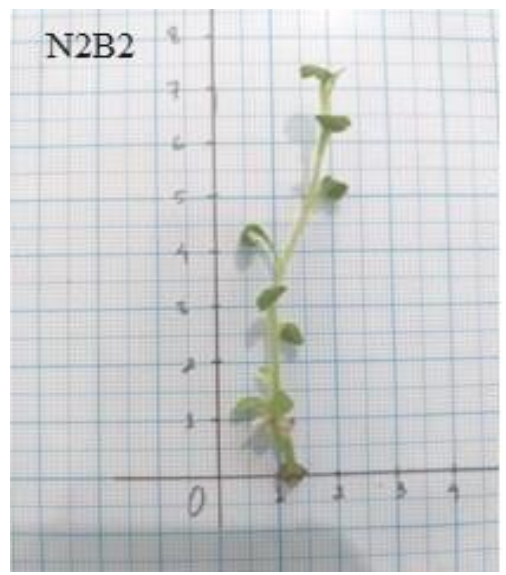

Figure 1:-Documentation of the number of leaves in the N2B2 treatment

The matter also supported by the administration of auxin in optimum concentration, the plant responses to obtain the equality of growth regulator concentration in the cells which determines the leaf formation (Widiastoety, 2014). Auxin transportation in transport media to the shoot causing the leaf formation and the rate of photosynthesis will arise as well as the growth of leaves daun (Rachmawati et al., 2017).The observation result shows the administration of NAA and BAP is not significantly affecting the plant height. Over administration of the growth regulators might causing small plantlet or stunted plantlet. This is in the accordance of Magdalena (2002) who states that growth regulator in plants might work effectively in particular concentration.

Exorbitant concentration might cause the inhibition of endogenous cytokinin synthesis and interfere the cell division.The plant height is noticed by the division and elongation of the cells until the plant is visibly escalating. This activity is affected by few growth regulators (Abidin, 1994). The important role of auxin and cytokinin are reprogramming somatic cells which are going to determine the next dedifferentiation. Growth regulator balance is highly required to regulate the growth in certain phase. This shows that the administration of NAA towards BAP in MS medium is not giving any positive respond to the growth of height of the plant, yet significantly affecting the leaves number. During plant height observation, every plantlet didn't show to have significant difference in growth of height (Kartina, 2012). Some plant cells may grow and developed and regenerate to a new plant in the medium without the administration of any hormone (Marlin, 2005).Therefore, without any external auxin and cytokinin, the height growth is going to arise as the normal plant, with the use of Murashige and Skoog (MS) medium, the explant of Chrysanthemum has given a good respond to the height growth to the basic character of the medium which is rich of nutrition 


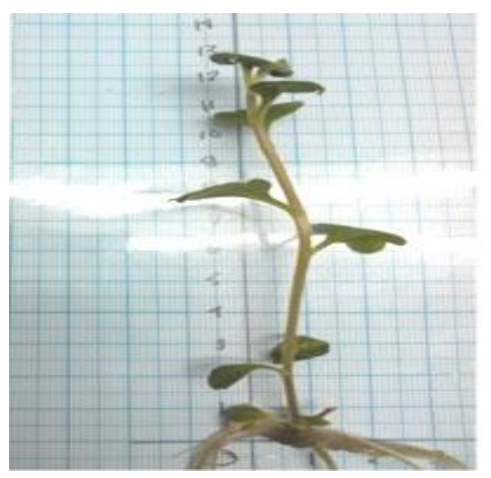

Figure 2:-Documentation of Plant Height in Treatment of N0B0

The administration of NAA and BAP is not significantly affecting the root number of the plant. According to Su et al. (2011) states that the addition of cytokinin in high concentration to the medium is going to inhibit the root growth, by its activity in the auxin biosynthesis inhibition to form the roots.
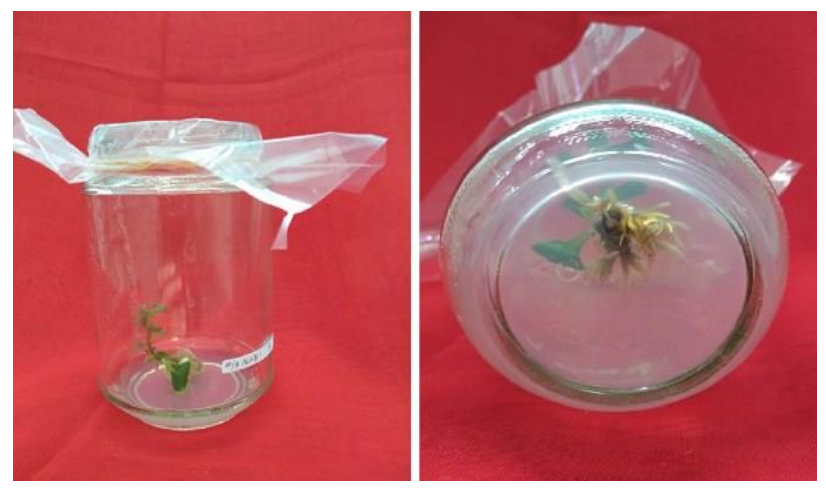

Figure 3:-Documentation of Root in treatment of N2BI

The best combination to the root growth has found in the treatment of N2B1. This is caused by the high dose of the auxin in the MS medium, that NAA is directly taking role of the root growth stimulation. The occasion has been strengthened by the statement of Harjadi (2009), NAA is taking role of callus growth, stimulate the cell division and regulating the morphogenesis. According to the performed observation, root growth occurred in the eighth week. In case the observation performed longer in time, the combination of NAA and BAP treatment may result better effects in root growth. An indicator of successful tissue culture of plant is the accretion of the root.

Root is a plant organ which works as food supplier to the whole plant body and as absorber of nutrition to grow and develop. Observation parameter to the NAA and BAP administration treatment didn't show any significant affection towards the root length of the plant. This might cause by the cytokinin high concentration compared to the auxin concentration, with the result that auxin work as root growth promotor was inhibited by the cytokinin. This is in line with Karjadi (2007), with the increasement of cytokinin, the roots forming tend to decrease, assumed that the root growth in plantlet was inhibited by the addition of BAP. There should be a balance amount of growth regulators ingredients to the medium, as Rahardja (2007) has stated that the growth respond of the cultured explant depends on the interaction and counterpoise of the endogenous regulator and exogenous compound given to the medium. 

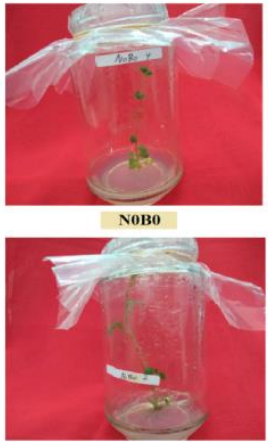

N1B0

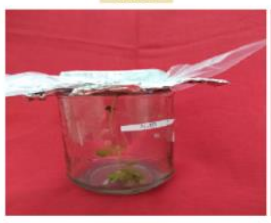

N2B0

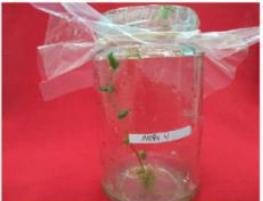

NoB1

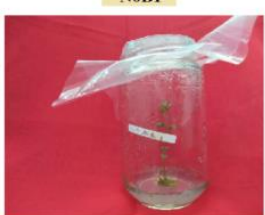

N1B1

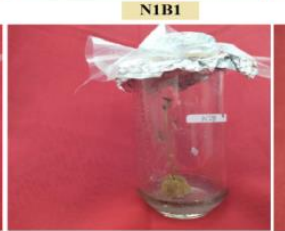

N2B1

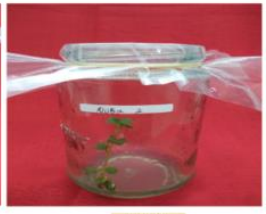

NoB2

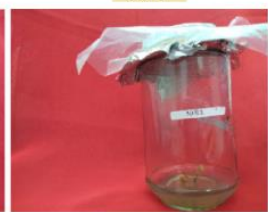

N1B2

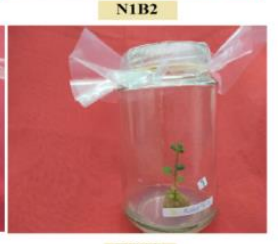

Figure 4:-Chrysanthemum propagates in various treatments in eight weeks of propagation.

During the observation, plants shows there was callus formed seems to cover the lower branch as appeared in Fig. 5 in the treatment of N2B1 and N2B2. This might occurr by the use of the explant of former tissue culture of Chrysanthemum and there might be unintentional cuts or scars from the piece of the explant had damaged and breakdown of the cells occurred. It causes the cells produce compounds which stimulate the cell division in the next layer to form clumps of differentiated cells (Astutik, 2007). Observation show after few repetition of N2B2 and N2B1 treatment appear to have callus growth in the fourth week after the propagation process.

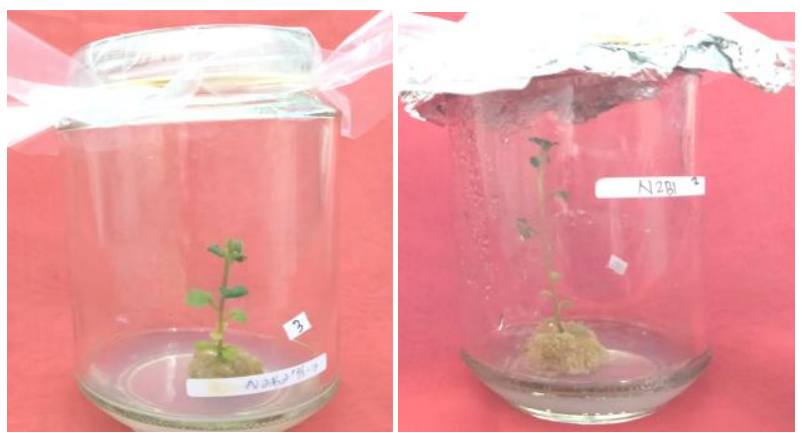

Figure 5:-Documentation of callus treatment of N2B2 and N2B1

Callus growth is marked by the whitish yellow swell in the cutting scar of the explant causing the coverage of it. Callus formation of the explant also affected by the growth regulator added to the medium especially auxin and cytokinin. Callus inducement by administration of auxin often combined with the cytokinin well known as Benzyl Amino Purin (BAP).The administration of auxin and cytokinin to the culture medium may increase the growth regulator concentration endogenously, which become a factor of the growth and development of the tissues (Lestari, 2011) Generally, shoot will be formed when the cytokinin dose higher than auxin and callus will not be differentiate when the cytokinin is lower than auxin (Mahadi, 2016). According to Yustina (2004), in case both cytokinin and auxin are high makes possible for the stimulation of shoot formation. Yet when both hormones are in low concentration, the root formation would be stimulated. And when both hormones concentration are balanced, the callus formation will occur.

\section{Conclusion:-}

In vitro propagation of Chrysanthemum plant (Chrysanthemum indicum L) with supplementation of NAA and BAP significantly affecting the leaves number and non significantly affecting the number of roots, height and root length. 


\section{References:-}

1. Abidin, Z. 1994. Fundamentals of Knowledge of Growth Regulatory Substances. Bandung: Space

2. Altayani, A., Suaria, N., and Arjana, M, G, ... Length of cuttings and Rootone-F on growth and cuttings of chrysanthemum plants (Chrysanthemum, sp). Journal of Agro Echoes, 23 (2): 139-145

3. Astutik 2010. The use of alar and BA (Benzyl adenine) in chrysanthemum tissue culture media. Buana Science 1 (10): 77-82

4. Harjadi, S.S. 2009. Growth Regulatory Substances. Swadaya Spreader Publisher, Jakarta

5. Karjadi, A.K. and Buchory, A. 2007. Effect of NAA and BAP on the Growth of the Garlic Meristem Network on Media B5. J. Hort 17 (3): 217-223.

6. Kasli, 2009. Propagation Effort for Chrysanthemum (Chrysathemum sp) In Vitro. Straw 2. (3): 121-125

7. Lestari, E.G. 2011 The Role of Growth Regulatory Substances in Plant Growth through Tissue Culture. AgroBiogen Journal 7 (1): 63-68

8. Magdalena (2002) Magdalena, T.S., L. 2002. Effect of Cytokinins on in Vitro Morphogenesis and Ploidy of Pepper Capsicum annuum L. Electronic Journal of Polish Agricultural Universities, Agronomy-my, Vol. 5. Issues 1.

9. Mahadi, I. 2016. The Effect of Giving Naphthalene Acetyl Acyd (NAA) and Kinetin Hormone in Bogor Pineapple (Ananas comosus (L.) Merr.) Tissue Culture cv. Queen. Bio-site, 2 (2): 27-31.

10. Muhit A. 2007. Early Production Technique of Chrysanthemum (Chryantemum morpholium) Vegetative Seed. Agricultural Engineering Bulletin 12 (1). 14-18.

11. Ni'ah, F. Ratnasari, E. S, Luke. and Budipramana. 2012. The Effect of Giving Various Combinations of Sucrose and Kinetin Concentrations to the Induction of Potato Micro Tubers (Solanum Tuberosum L.) from In-Vitro Flower Granola. LanternBio, 1 (1): 41-48

12. Rachmawati, D. L., Roviq, M and Islami, T. 2017. Atonic Composition and Coconut Water on the Growth of Bud Cane Chips (Saccharum officinarum L.). Journal of Plant Production, 5 (5): 851-859.

13. Rahardja, P.C. 2007. Modern Plant Propagation Techniques. Swadaya Spreader Publisher, Jakarta.

14. Soedarjo. 2010. Chrysanthemum Innovation Business Opportunities Agricultural Research Agency. South Jakarta: Agro-innovation

15. Su, Y., Liu, Y., and Zhang, X. 2011. Auxin cytoknin interaction regulate meristem development. Molecular Plant, 4 (4): 616-625.

16. Sugiyanto. 2008. Effect of BAP and NAA Giving on the Growth of Chrysanthemum (Chrysantemum morpholium) in Tissue Culture. Biota X (3): 31-35.

17. Widiastoety. A, Santi. and N, Solvia. 2012. Effect of Myo-inositol and Active Charcoal on the Growth of Dendrobium Orchid Planlets in In Vitro Culture. J. Hort. 22 (3): 205-209, 2012

18. Yusnita. 2003. Tissue Culture How to Efficiently Increase Plants. Agromedia Reader. Jakarta. 105 pages

19. Yustina, 2004. In Vitro Propagation of Orchid Plants. Bandar Lampung: Publisher of the University of Lampung. 